\title{
Christian Zionist Religiouscapes in Brazil: \\ Understanding Judaizing practices and Zionist inclinations in Brazilian Charismatic Evangelicalism
}

\begin{abstract}
The increasing appropriation by Charismatic Evangelicals of Jewish narratives, rituals, and even Zionist anxieties is now evident in many parts of the globe. Drawing on two cases, one based on a Brazilian Neo-Pentecostal church and another one based on an ethnographic investigation of a 'Judaizing Evangelical' community in Brazil this study interrogates to what extend we can comprehend this emerging tendency within Brazilian Charismatic Evangelicalism as a result of the spread of Anglo-American Christian Zionism. The paper contends that while there are significant overlaps between Anglo-American Christian Zionism and the Zionist and Judaizing tendencies within Brazilian Charismatic Evangelicalism, it is reductionist to comprehend the Brazilian case exclusively through Anglo-American frameworks. Given the particularities of the Brazilian Charismatic evangelical context, the paper points to the unique ways in which Christian Zionist tendencies are being 'glocalized' in the country.
\end{abstract}

Keywords: Christian zionism, globalization of religion, neo-pentecostalism, Brazil, judaizing groups

Paysages religieux sionistes chrétiens au Brésil: Pratiques judaïsantes et inclinations sionistes dans l'évangélisme charismatique brésilien

L'appropriation croissante par les évangéliques charismatiques des récits et des rituels juifs, et même des angoisses sionistes, est maintenant évidente dans de nombreuses régions du globe. En s'appuyant sur deux cas, I »un basé sur une église néo-pentecôtiste brésilienne et l'autre, sur une enquête ethnographique sur une communauté "évangélique judaïsante» au Brésil, cette étude pose la question de savoir dans quelle mesure nous pouvons comprendre cette tendance émergente au sein de l'évangélisme charismatique brésilien comme étant un résultat de la propagation du sionisme chrétien anglo-américain. L'article soutient que, bien qu'il y ait des chevauchements significatifs entre le sionisme chrétien anglo-américain et les tendances sioniste et judaïsante au sein de l'évangélisme charismatique brésilien, ce serait réducteur de comprendre le cas brésilien exclusivement à l'aune des cadres anglo-américains. Étant donné les particularités du contexte évangélique charismatique brésilien, l'article souligne les façons uniques dont les tendances chrétiennes sionistes sont «glocalisées» dans le pays

Mots-clés: Sionisme chrétien, mondialisation de la religion, néo-pentecôtisme, Brésil, groupes judaïsants

Bio: Manoela Carpenedo holds a PhD from the University of Cambridge. She is a postdoctoral researcher at the Institute of Latin American Studies, School of Advanced Studies, University of London. 


\section{Introduction}

The increasing appropriation by Charismatic Evangelicals ${ }^{1}$ of Jewish narratives, rituals, and even Zionist anxieties is now evident in many parts of the world. The extent to which this movement has grown is evident in its engagement within the socio-political landscape: an example is the evangelicals' expression of praise for the United States' decision to relocate its embassy in Israel from Tel Aviv to Jerusalem. Similarly, Brazilian Pentecostals now demand the far-right President Bolsonaro fulfils his campaign promises and move Brazil's embassy to Jerusalem. Inspired by the scholarship aiming at investigating the interplay between contemporary religion and global entanglements, this paper seeks to understand a growing tendency in Brazilian Evangelicalism which combines Christian theological teachings, Jewish symbols, and Zionist political anxieties. The paper interrogates to what extend we can comprehend this grassroots tendency within Brazilian Charismatic Evangelicalism as a result of the spread of Anglo-American Christian Zionism.

This article contends that, although one can easily trace some similarities between AngloAmerican Christian Zionism and the Zionist and Judaizing tendencies within Brazilian Charismatic Evangelicalism; it is a mistake to comprehend the Brazilian case exclusively through North American frameworks. While there are significative overlaps between Brazilian and Anglo-American Christian Zionist forms, my findings suggest that rather than mimicking the theological, political and social characteristics of North-American Christian Zionism; the Brazilian case presents distinct characteristics which have to be understood in light of the particularities of the Brazilian Charismatic Evangelical field.

In terms of methodology, this study is based on a comparative socio-historical revision between Anglo-American Christian Zionism and what we could refer as the Brazilian Christian Zionist 'religiouscapes'. This comparative analysis draws on selected primary and secondary sources on the ways in which a Neo-Pentecostal church - the Universal Church of the Kingdom of God (UCKG) - has been articulating some Jewish symbols and artefacts in its religious program. This analysis is complemented with an ethnographic fieldwork among a 'Judaizing Evangelical' community in Brazil. Between 2013 and 2015, I conducted fieldwork within a network of former Charismatic Evangelical congregations going through a dramatic adoption of Jewish practices. Besides numerous in-depth interviews with members, my 
ethnography encompassed, participant observation in religious services, Hebrew lessons, religious teachings and a two weeks long travel to Israel with a group of women.

In the first part of this article, I discuss the current debates on religion and global entanglements, subsequently I brushstroke the Anglo-American Christian Zionist field. In the following sections I move to the analysis on how Jewish symbols and Zionist inclinations are being articulated in the Brazilian Charismatic Evangelical field.

\section{Religion and Global Entanglements}

With religion emerging as a key element in the analysis of globalization and its impacts on contemporary societies, the concept of 'Glocalization' has served as a dialogical approach able to capture the entanglements of the global and the local within globalised cultures (Robertson, 1995). This approach prioritises cultural mobilities and connectivity between spaces and places. Therefore, instead of focusing on a given culture with pre-established geographical borders, scholars turn to transnational networks and flows or as Appadurai established 'scapes'. My research is substantially informed by this framework, as I find particularly fruitful the ideas of Ethnoscapes (the flows of people across the planet) and what some recent observers have been calling 'religioscapes' (McAlister, 2005). In this framework, religioscapes would be inherently fluid. As people move within diasporic and migratory flows, religious practices would follow such displacements and spreading around the globe. A good example of this is the fact that the 'importation' of new religious cultures (Castro \& Dawson, 2017) is now a reality in many parts of the globe.

While I find this perspective essential to understand current religious realities, I also think that it is important to map how certain cultural ideas interact with localised movements in a way that this contact creates novel forms and practices that exist independently from its precedent forms. My investigation on the ways in which Judaizing practices and Zionist discourses are being mobilized within Brazilian Charismatic Evangelicalism reveals that there is a need to include local adaptations when analysing contemporary religiouscapes.

Therefore, this paper contends that one has been very cautious when defining Judaizing practices and Christian Zionist tendencies in Brazil only through its similarities to North American frameworks. While substantially influenced by Anglo-American Christian Zionism, 
my investigation contends that cultural adaptations are key to understand the growth and appeal of Judaizing practices and Zionist inclinations in Brazilian Charismatic Evangelicalism. By exposing the diversity of what we could call 'Christian Zionist religiouscapes', this article demonstrates how the Brazilian case complicates the prevalent Anglo-American frameworks in the literature.

\section{The roots of Anglo-American Christian Zionism and its influence in American identity}

Historiography has found that early Christian Zionist sentiments can be traced as far back as in the writings of British bishop, John Bale (1495 - 1563). By emphasising anti-Catholic, Judeocentric and historiographic elements, these embryonic Zionist inclinations became important to British Evangelical identity as 'a way of further distinguishing Protestantism (apostolic Christianity) from its Roman Catholic and Tractarian counterfeits' (Lewis, 2014: 102).

While debatable, many scholars have pointed out the role played by Dispensational theology in the development of Zionist sentiments among Christians. Dispensationalism is an eschatological worldview disseminated by John Nelson Darby, an Anglican priest in the Church of Ireland in the $19^{\text {th }}$ century. Dispensationalism teaches that the Jews are central to the unfolding of biblical prophecy. It claims there are fundamental distinctions between the divine plans for Israel (the Jews) and the New Testament Church. This differs substantially from mainstream Christian doctrines that follow the belief that the Christians have replaced the Israelites as the chosen people of God. Christians espousing Dispensational viewpoint believe that the return of the Jews to the Holy Land and their subsequent conversion to Christianity is a prophetic condition for the realization of the Kingdom which will culminate with Jesus' reign of heaven on Earth. Without the return of the Jews to Israel, there will be no second coming of Christ, and no resurrection and eternal life in the heaven on Earth.

Although Dispensationalism alone is not able to explain contemporary Christian political activity on behalf of Jews or the State of Israel in the U.S. (Westbrook, 2014), it is prudent to stress the role of Darby's Dispensationalism in the development of Anglo-American Christian Zionist forms. Between 1862 and 1878, Darby propagated his ideas in the U.S, where his doctrine was gradually absorbed into American Christian thought. A good example of how Darby's theological ideas are present in American religious consciousness is the popularity of 
his elaborations of the Rapture event. The rapture event suggests that at the end of times, before the Great Tribulation (a period characterised by wars and disasters) Christians believers will be miraculously raptured from the world and meet Jesus in the heaven. According to this view, the Rapture event would pave the way for Jesus second coming. A Pew research among Christian leaders in the US from 2011 found that Six-in-ten leaders (61\%) believe in the Rapture of the Church. Similarly, 63\% of American Christians said that believe in the Rapture of the Church (Pew, 2006).

Historiography indicates that Christian Zionism has an important role in the formation of American national identity (Smith, 2013). English colonists found in the biblical narratives of the Children of Israel the vocabulary to describe their unique (exceptional) vocation. William Eugene Blackstone, a key founding figure of the Christian Zionist movement in the 19th century in the U.S., mobilised these ideas into the political arena. Commonly cited as the rationale for the restoration of the Jewish state by early and contemporary Christian Zionists, Genesis 12:3 reflects the idea that God would bless/reward those nations that protect Israel and curse/punish those that are against Israel. As an evangelist, Blackstone theorised and propagated the idea that America had a special role in God's plan to help humanity. Because of its moral superiority over the other nations, God would have chosen America to lead Jews to their return to Jerusalem. Yet, with 'greater power comes with greater responsibility' Americans would be judged - by God - according to the way it carries out its mission. In this apocalyptically-conceived articulations of American identity, we see not only the ways in which that Jewish and American identities become intertwined, but also how this relationship became constitutive of American national identity (Smith, 2013).

In 1948, with the creation of the State of Israel, American Evangelicals holding Christian Zionist understandings were enthusiastic and followed the establishment of the Jewish state with great interest, seeing it as an advancement of God's plans (Ariel, 2006). The formation of physical Israel was a clear sign that the present era was terminating and the events of the End Times were about to unfold. Christian Zionists were firmly convinced of the faithfulness of Scripture and its prophecies, views that were only reinforced by dramatic Israel's victory in the 1967 Arab-Israeli Six-Day War (Ariel, 2006). 
From its early roots in Britain, passing through the development of American

'Dispensationalism' in $19^{\text {th }} 20^{\text {th }}$ century, to a key element in the formation of American national identity (Smith, 2014), Anglo-American Christian Zionism is an established feature of U.S. religious and political landscape. Although it is impossible to tell the story of contemporary Christian Zionism without taking into account the emergence of the Religious Right as a formidable force in American politics (Williams, 2015), we have to careful and not simplify the history of Anglo-American Christian Zionism to the conservative evangelical support for Israel. Moreover, I agree with Westbrook (2014) on the overemphasis of Dispensationalism given in the literature on American Christian Zionism. According to him there is a need to include the different logics beyond Darby's Dispensationalism to avoid reductionist accounts on the phenomenon. This is not the only bias I see in the literature. While I am aware of the diversity of Christian Zionist expressions in the U.S., having no fixed theological understanding, I see the need to decentralize the Anglo-American case for understanding Christian Zionism on a global scale. For instance, the particularities of the Brazilian Charismatic Evangelical field indicates the different ways in which the movement is 'glocalising' in the world. By comparing the similarities and the differences of the Christian Zionist case in Brazil and the US, this article contributes to the understandings of how 'Christian Zionist religiouscapes' are articulated around the world.

\section{Importing Anglo-American Christian Zionism?}

I now examine how Anglo-American Dispensational ideas and Zionist inclinations are being articulated in the Brazilian Charismatic Evangelical field. I start my analysis by investigating the emergence of Dispensationalism in Brazilian contemporary Christian culture. Particular attention will be given on the ways these ideas compare to the U.S. case and are 'glocalized' within the Brazilian religious mediascapes such as religious magazines and telenovelas. Subsequently, I explore the ways in which a Neo-Pentecostal church is assimilating Jewish narratives and symbols.

Scholars have pointed out the ways in which Brazilian Evangelicalism has been open to the influence of North-American forms, having enthusiastically embraced many of the theological and institutional innovations brought by North American missionaries (Mariano, 1999). Combined with cultural and economic narratives of North-American superiority, social 
cohesion and economic abundance (Schwarz, 1992), North-America would emerge in the discourse of many Brazilian Charismatic Evangelical denominations as a mythical place 'an earthly paradise' to be emulated.

Before analysing how American innovations arrived in Brazil, it is important to stress the differences between the Charismatic Evangelical field in Brazil and in the U.S. The Brazilian Charismatic Evangelical field is immersed on what Bittencourt Filho (2003) defined as the 'Brazilian religious matrix'. Informed by Iberian Catholicism, native Amerindian religions, African possession cults the 'Brazilian religious matrix' combines the spiritual, the natural and the mundane. Brazilian Charismatic Evangelical expressions have been very successful in rearticulating many of these elements in their theology and practice - in healing and exorcism practices for example. Therefore, it is within this context, that Christian Zionist ideas have been embraced in Brazil.

A good example of how North-American theological ideas found a fertile terrain in Brazil is the case of Dispensational theology. While very fragmented and infused by local elements, it can be said that some Brazilian Evangelical groups, particularly those embracing NeoPentecostal beliefs, are attracted to some of the theological ideas of Darby's dispensationalism. An important outlet in the dissemination of Dispensationalism in Brazil is the magazine Midnight Call 'Chamada da Meia-Noite' (Maynard, 2016). Informed by NorthAmerican Dispensationalism, Dutch missionary, Wim Malgo founded the magazine in 1955 to expand protestant prophetic teachings. The monthly magazine printed in Porto Alegre has a literal take on the Bible and displays a strong focus on classic themes of Darby's Dispensational eschatology, such as biblical prophecies, the Rapture and the second coming of Jesus. The magazine demonstrates a clear Dispensational understanding of global history where Israel and its narratives have a privileged place (Maynard, 2016). For example, the July 2020 issue features in its cover topics dear to Dispensational theology; such as 'Israel as a sign' and 'Israel: the chosen people of God'. Although the impact of the magazine at the grassroots level can be questionable, because of the overall lack of interest in theology per se which characterises Neo-Pentecostalism, the 'Midnight Call' can be seen as an important tool in the dissemination of dispensationalism in Brazil. 
Media plays also an important role in understanding the development of Christian Zionist religiouscapes. For instance, in the US, Christian Zionist ideas are very popular in evangelistic channels. According to Westbrook (2014) channels such as TBN and Daystar not only offer the emotionally-charged narratives but also the imagery so important to establishing the Christian Zionist ideology. With strong similarities to their American counterparts, such as high degrees of social conservatism, charismatic theology and the influence of the prosperity gospel, more and more one can find Christian Zionist ideas in Brazilian religious-mediascapes via evangelistic channels where we can find certain forms of Dispensationalism featuring in telenovelas - very popular serial dramas in Latin America.

Since 2010, evangelical Record TV network has been producing telenovelas exploring different biblical texts, particularly those of the Old Testament, from 'Esther' (2010) to 'Joseph in Egypt' (2013) to its greatest hit Ten commandments' (2015). Record TV network is owned by the UCKG. Although these biblical telenovelas are designed and targeted almost exclusively to the Brazilian 'gospel market', the latter had a remarkable success among working class urban Brazilians. Darby's Dispensational ideas are gradually becoming a theme at Record TV telenovelas productions. In 2019, a telenovela named Apocalypse was aired featuring eschatological themes from a dispensational perspective. Divided into 3 main arcs, the telenovela explores topics such as the emergence of the antichrist, the Rapture, the earthy turmoil of the end of times and the preparation for Jesus second coming (Araújo \& Santana, 2019). A clear distinction between Christian believers and non-believers is delineated in the plot, where only the righteous ones partake in the Rapture event. Therefore, a Brazilian cultural icon such as a telenovela based on Dispensational teachings demonstrates how the global and the local are being 'glocalized' in the formation of Christian Zionists religiouscapes in Brazil

Another good example on the ways Christian Zionist narratives and Jewish symbols are being materialised in Brazilian Charismatic Evangelicalism can be found in the use of Jewish narratives and symbols by the UCKG. The symbolic approximation with Judaism in the UCKG can be seen through the display of certain Jewish symbols such as the Star of David, the menorah (multi-branched candelabra), and the tallit (prayer shawl) in UCKG temples (Topel, 2011). This relationship between the UCKG and Jewish symbols reached its pinnacle in 2014 when Edir Macedo inaugurated a replica of the 'Temple of Solomon'. 
Located in the outskirts of São Paulo, the temple emulates the original temple of King Solomon as described in Chronicles (chapter 2). Costing around $\$ 230$ million dollars, it is built using stones from Jerusalem imported from Israel. According to Edir Macedo in the temple's inauguration speech, 'the temple is a way to bring believers closer to Jerusalem' (Macedo 07/2014). The UCKG extravagant inauguration of Temple of Solomon showcased a number of Hebraic symbols and paraphernalia.

Researchers have explained the rationale behind the UCKG's unexpected adoption of Jewish symbols, particularly the colossal construction of the 'Temple of Solomon,' as representing the symbolic consolidation of the church in the religious field. Here, the material connection with Jerusalem would play an important role in the construction of UCKG's religious authenticity, as the outskirts of São Paulo would become part of the 'Holy Land'. Therefore, the Temple of Solomon would not only give legitimacy to this recent Neo-Pentecostal global network, but it would also represent the final institutional consolidation of this new religious powerhouse (Oro and Tadvald, 2018).

While this appropriation of Jewish-themed rituals by Brazilian Neo-Pentecostals can parallel to some extent, with what Williams (2015) called the 'Pentecostalization of Christian Zionism', there some distinctions that need to be traced. According to Williams, Pentecostals longing an authentic religious experience would establish an experiential identification with Israel as a real, concrete place. The growing religious diversity in the U.S would have facilitated Pentecostals' renewed experimentation with 'exotic' Israel-themed rituals (Williams, 2015). While Jewish themed rituals can bring an experiential dimension-so dear to Pentecostals anywhere-we have to be careful to understand the Brazilian NeoPentecostal move towards Jewish-themed rituals through the American 'born-again seeker' archetype (Roof, 1993). For instance, Brazilian Neo-Pentecostal's economic, ethnic and cultural contexts are dramatically different from the white middle-class American babyboomer believers identified with born-again Christianity and Jewish-themed rituals, who are highly literate and Internet-savvy (Kaell, 2016). To understand the embrace of Jewish-themed rituals by Brazilian UCKG, we have to consider the particularities of the Brazilian Charismatic Evangelical field characterized by high competition, interaction with indigenous religions, and very little interest in theology. 
According to Topel (2011), the UCKG's embrace of Jewish symbols and narratives has an institutional dimension, as it would be a way that the UCKG is rebranding itself in order to differentiate its 'religious product' within the highly competitive Brazilian religious market. She warns us of the UCKG inconsistency regarding their use of external symbology 'which can go from Catholicism, Afro-Brazilian cults, New Age and even secular elements'. In a similar vein, Lehmann (2020) argues that the UCKG adoption of Jewish-themed rituals and symbols would have only an incidental place. Rather than creating a legitimated narrative associating the church with Anglo-American forms of Christian Zionism, the UCKG would not be interested in formulating a cohesive theology but in constructing its own institutional lineage. Although the UCKG temples and aesthetics display biblical themes from Sinai, neither Jewish or any sort of Christian Zionist theologies are taken seriously by the UCKG (Lehmann, 2020). Therefore, Jewish themes, prophecy and Christian Zionist ideologies would be mobilised only at a superficial level as the UCKG theological program would be still focused on healing, prosperity gospel and exorcism directed against the pantheon of Afro-Brazilian religions.

The case of the UCKG and its arbitrary use of Jewish-themed symbols illustrates the differences between the ways in which Christian Zionist ideologies are being understood in Brazil and the U.S. While Pentecostals in the U.S. connect their approximation to Christian Zionism and Jewish themed rituals with the desire of an authentic religious experience, Brazilian Neo-Pentecostals appear to be engaging in a superficial way with Jewish symbology, as believers would respond to UCKG inconsistent use of external symbology. Moreover, the way in which Jewish symbols and Christian Zionist ideologies are presented to believers radically differs in these two cases. While one finds in the U.S, a bottom-up approach, where savvy 'born-again seekers' look for cerebral theological experiences through experimentation with Israel-themed rituals; in the Brazilian UCKG, members are not avidly seeking Jewishthemed experiences, being more interested in UCKG's healing and deliverance rituals. Therefore, what we have is top-down approach where a Neo-Pentecostal church looks for material and symbolic consolidation through its connection to Judaism and Jewish symbols.

When analysing a bit further how Christian Zionism is taking shape in Brazilian, it is also relevant to consider the ways in which some embryonic Zionist narratives are being articulated in Brazil's socio-political terrain. As explored, Christian Zionist narratives are not only relevant for understanding aspects of American identity, but also to comprehend U.S. 
geopolitics. In 2017, U.S. Zionist inclinations became explicit when the Trump administration decided to recognize Jerusalem as Israel's capital. The affirmation of Christian Zionist values in the U.S also impacted Brazil. For instance, since the election of the far-right President Bolsonaro, Brazilian Charismatic Evangelicals have demanded the recognition of Jerusalem as Israel's capital, despite Brazil's decades-long pro-Palestine geopolitical alignment. Illustrating this new Israel - Brazil association, Israeli prime minister Benjamin Netanyahu went to Bolsonaro's inauguration in January 2018 and announced that a new diplomacy was about to start: 'Israel is the promised land, Brazil is the land of promise'. Echoing this connection between Brazil and Israel, President Bolsonaro has been seen multiple times mobilizing Zionist symbols, in May 2020, he gave a speech next to the Brazilian and Israeli and American flags.

In the U.S., Christian Zionist movements are often either directly connected with Dispensational theology or to ideas of American national identity as bound with Israel as a chosen nation (Smith, 2010). While in Brazil one finds Bolsonaro utilizing Israeli flags in his public speeches, neither narratives of national exceptionalism, nor political theological references on the prophetic role of Brazil in leading Jews to their return to Israel are clearly articulated. Therefore, instead of articulating a national theological project, these Zionist manifestations in Brazil could be simply demonstrating a rallying call to the political rightwing by Bolsonaro's administration. In this case, it would be reductionist to affirm that Brazilian Evangelicals are simply following the same Anglo-American model - where the mobilization of Zionist sentiments and apocalyptic narratives are an important part of American national culture and identity. As the next section of this article demonstrate, the incorporation of Judaizing elements and Zionist rhetoric into Christianity can assume a very different function within the Brazilian religious context.

\section{Reforming Christianity through Judaism: The Judaizing Evangelicals in Brazil}

To further investigate the different ways that 'Christian Zionist religiouscapes' are taking shape in Brazil, I now move to the case of the 'Judaizing Evangelicals' in Brazil. By exploring how some Charismatic evangelical churches are incorporating Jewish elements into their rituals and doctrine, I hope to demonstrate how some Brazilian Charismatic Evangelical groups are creating different meanings for their approximation to Judaism. 
Between 2013 and 2015, I conducted fieldwork among the 'Judaizing Evangelicals' in of Brazil to examine the radical approximation to Judaism of a charismatic evangelical network of churches. The grassroots movement proposes a dramatic adoption of an Orthodox Jewish rules and ethos among people who were not born into Jewish families. To differentiate these emerging groups from other tendencies found in American-Christian Zionism or in UCKG Neo-Pentecostalism, I coined the term 'Judaizing Evangelicalism' (Carpenedo, 2018). The organization is composed by a network of middle to small congregations spread in urban and rural parts of Brazil, totalizing nearly 8.000 members. The member of the Judaizing Evangelical community I studied are mostly from working-class and low middle class backgrounds, with relatively little education. Members have no Jewish background and before becoming Judaizing Evangelicals, they all had previous affiliation at Charismatic Evangelical churches (such as UCKG and Assembly of God). Instead of mobilising strong Zionist geopolitical sentiments (like Christian Zionists in the U.S.) or building extravagant temples (like the UCKG), the Judaizing evangelicals I worked with are adopting Jewish tenets and rituals into their Christian lives.

Unlike American-Christian Zionists, the Judaizing Evangelicals find authority for their religious project in their own theological approximations to Talmudic teachings and other post-biblical Jewish literature. During the course of my fieldwork, I had the chance to witness how this radical religious change towards Orthodox Judaism was taking place in the life of these former Charismatic Evangelicals. Surprised, I watched the incorporation of Jewish rituals in members lives-male adults, teenagers, and children underwent circumcision; kosher food was incorporated in members' diets; and increasing numbers of women chose to respect menstrual taboos and strict codes of modesty in dress. They did all this without showing any interest in converting to or being recognised by mainstream Judaism. On the contrary, the community seeks to extend its influence among Christian believers. The Judaizing Evangelicals see themselves as playing an important role in the diffusion of Torah knowledge and practices among Christians being: 'the light within the pagan Christian nations' (leader, sermon 2015).

My research contends that 'Judaizing Evangelical' communities should be understood as a revival movement seeking to restore Charismatic Evangelicalism, mainly influenced by NeoPentecostal tenets. For the Judaizing Evangelicals, the incorporation of Jewish elements aims 
to rebuild the authenticity of Christianity while distinguishing them from Charismatic Evangelicalism. By turning to the supposed roots of Christianity's 'Judaism', these former Pentecostals want not only to emulate the ethos of the early church but also purify degenerated Charismatic Evangelicalism. By incorporating the religious laws of Judaism, the Judaizing Evangelicals seek to establish a clear distinction between themselves and what they see as deteriorated Charismatic Evangelicalism characterised by scriptural superficiality, moral permissiveness, materialism and emotionalism. According to the Judaizing Evangelicals, the Charismatic Evangelical world is 'shallow' and 'morally degenerate' being illequipped to enforce righteous conduct among its followers.

A good example is their criticism of the prosperity gospel taught in many Neo-Pentecostal churches. This theological teaching promises 'wealth and health' to its followers, while asking for offering and sacrificial giving to the church. During my time with the 'Judaizing Evangelicals,' I noticed that they rejected this dimension of their past Christian beliefs. One of my informants, Dinah, a retired house cleaner in her mid-fifties, talks about her previous experiences in a Neo-Pentecostal Brazilian church with a strong focus on the prosperity gospel:

My former church was so different. They were very focused on healing and material prosperity. They were much more worried about our material life than our spiritual one. I used to find this approach to prosperity so wrong. (conversation at the synagogue, 2015)

As Dinah's narrative illustrates, focus on worldly and the material dimension of prosperity gospel propagated by their former churches is now rejected by Judaizing Evangelicals. The need to ask for 'endless material blessings from Jesus' as another informant puts it, is gradually replaced by the need to live according to the Jewish rituals and lifestyles, which are resignified in their own terms by the Judaizing Evangelical hybridisation process.

This community, also repudiates the supernatural elements found in their former churches. These critiques are also accompanied by a rejection of the emotional and cathartic experiences found in Charismatic 'spiritual warfare', including the centrality of evil/demons, deliverance rituals (exorcism), and manifestations of 'gifts of the spirit' such as speaking in tongues (Corten, 1999). As middle-aged Hadassa told me: 'The crente [believer] wants to live 
emotions, they go to church to have emotions, to feel things that they do not experience in their daily life. This is nonsense for me now'. This way of relating to one of the most important characteristics of Pentecostalism is unique. For instance, in the U.S Pentecostalized forms of Christian Zionism strongly privileges the connection with the supernatural (Williams,2015).

Judaizing Evangelicals completely reject the permanent state of spiritual warfare and the constant threat of the devil in their daily lives: 'devils do not exist', one member told me. They view these devils as residual 'paganism' and a deviation from the true faith preached by Jesus. The rejection of the dualist ontology, which establishes a world divided between satanic and divine forces, empowers the Judaizing Evangelicals to break with their past religious cosmologies. Therefore, in criticising elements of their religious past whilst adopting Jewish beliefs symbols and lifestyles, the Judaizing Evangelicals desire to move Charismatic Christianity away from its inaccurate interpretations.

The religious change has transformed the life and the religious identity of members. Now Jewish rituals and the adherence to a Jewish cultural repertoire attain paramount value in the lives of these former Charismatic Evangelicals. It is important to highlight that the Judaizing Evangelicals are appropriating the rituals and practices of Orthodox Judaism in their own terms. The Judaizing Evangelicals not only observe Jewish ritual and the festivities of the Jewish calendar but also - their own versions of - Mosaic laws such as Jewish dietary norms and the rules that regulate intimacy among married couples. Now, members of the community wear different garments, eat different foods, sleep with their husbands differently, and raise their children differently. Levi's sermon at the main synagogue (2015) is indicative:

We should think like a Jew, have the Jewish traditions in mind (...) Do you know the meat in the butchery? You cannot eat it anymore. Going to a gentile restaurant? Not anymore. The second step is the laws of purity. You must respect a woman's niddah (impurity)period.

Therefore, very differently from American Christian Zionist forms, which combines Christian apocalyptic narratives into national ideologies (Smith, 2013) or emphasises spirit-lift and supernatural forms of Christian expressions (Williams, 2015) for the Judaizing Evangelicals I worked with through the incorporation of Jewish symbols, laws and lifestyles, they aim to 
reform 'degenerate' versions of Christianity. Neither fully invested in Dispensational Christian theologies, nor in Pentecostalized forms of Christian Zionism (Williams, 2015) as their American counterparts, the example of Judaizing Evangelicals in Brazil complicates current elaborations on the Christians' symbolic approximations to Judaism. By reforming Christianity through 'Judaism', the case study of the Judaizing Evangelicals also demonstrates the unexpected ways that 'Christian Zionist religiouscapes' are glocalizing in Brazil.

\section{Conclusion}

Since I started conducting research on the incorporation of Jewish symbols and rituals by Charismatic Evangelicals in Brazil; scholars, observers, and even friends have asked me whether this phenomenon was similar to 'what was going on in the U.S..' This article investigated this question. While we can easily find some similarities between AngloAmerican Christian Zionism and these tendencies within Brazilian Charismatic Evangelicalism, particularly in the dissemination of Dispensational ideas through the Midnight Call magazine and Apocalypse telenovela, this study demonstrates that it is reductionist to comprehend the Brazilian case exclusively through Anglo-American frameworks.

From the construction of the colossal Temple of Solomon to a religious revival project aiming to restore Christianity through Talmudic study, this article exposes the multifaceted ways in which Christian communities are relating to Judaism and its symbols in the Brazilian religious field. Therefore, the presence of Christian Zionist sentiments in Brazil can be seen as a clear result of the transnationalisation of religious cultures. The globalization of religion facilitated the dissemination of foreign religious cultures; blurring previous geographic and cultural boundaries. In a way that, non-native narratives can be displaced and purposeful borrowed to justify and consolidate new practices.

By emphasising the accommodations and the cultural mutations of this trend in the Brazilian religious field this paper demonstrates that, at least in Brazil, 'Christian Zionist religiouscapes' cannot be understood only through its 'roots in modern American history' or through 'Darby's dispensationalism' as Gifford (2001) suggested in the context of African Christianities. As explored, differently from their North-America counterparts, some Charismatic Evangelical groups in Brazil are reforming Christianity through their 
approximation to Judaism. Moreover, among Brazilian UCKG followers, the embrace of Jewish-themed symbols cannot be read in light of current elaborations on the 'Pentecostalization of American Christian Zionism' (Williams, 2015). Instead of savvy 'borngain seekers' seeking authenticity through experimentation with Israel-themed rituals, one finds in Brazil a Neo-Pentecostal institution seeking material and symbolic consolidation through its connection to Judaism and Jewish symbols. In exploring how Christian Zionism can be understood (with and beyond) Anglo-American cases, my investigation found that cultural particularities and adaptations are key in understanding the growth and appeal of Judaizing practices and Zionist inclinations in Brazilian Charismatic Evangelicalism.

\section{Notes}

1. Movements that are inspired by the 20th-century Pentecostal Azusa Street Revival. Its theology stresses that: Jesus offers salvation; Jesus heals; Jesus baptizes with The Holy Spirit and Jesus is coming again.

\section{References}

Araújo G and Santana P (2018) A telenovela como dispositivo de encantamento religioso: uma análise da novela Apocalipse. In: Seminário Internacional De Pesquisas Em Midiatização E Processos Sociais. São Leopoldo, Brazil, 9-12 April 2018.

Ariel Y (2006) An Unexpected Alliance: Christian Zionism and its Historical Significance. Modern Judaism 26(1): 74-100.

Bittencourt Filho J (2003) Matriz religiosa brasileira: religiosidade e mudança social. Petrópolis: Vozes.

Carpenedo M (2018) Collective Memory in the Making of Religious Change: The Case of 'Emerging Jews' Followers of Jesus. Religion 48(1), 83-104.

Castro C and Dawson A (2017) Religion, Migration, and Mobility: The Brazilian Experience. London: Routledge.

Corten A et al (2001) Between Babel and Pentecost: transnational Pentecostalism in Africa and Latin America. London: Hurst.

Gifford P (2001) The complex provenance of some elements of African Pentecostal theology. In: Corten. A et al (eds) Between Babel and Pentecost. London: Hurst, pp. 62-80.

Kaell H (2016) Under the Law of God: mimesis and mimetic discipleship among Jewish-affinity Christians. J R Anthropol Inst 22: 496-515. 
Lewis D (2010) The origins of Christian Zionism: Lord Shaftesbury and evangelical support for a Jewish homeland. Cambridge: Cambridge University Press.

Lehmann D (2020). In thrall to the text: a Brazilian marriage of fundamentalism and hybridity. Politics and Religion in Brazil and the Americas, Haifa, Israel. 15-17 January 2020.

Mariano R (1999) Neopentecostais. Sociologia do Novo Pentecostalismo no Brasil. São Paulo: Loyola.

Maynard L (2016) O dispensacionalismo e a utilização de símbolos judaicos nos cultos evangélicos. Mphil Thesis, Universidade Federal de Sergipe, Brazil.

McAlister E (2000) Globalization and the Religious Production of Space. Journal for the Scientific Study of Religion 44: 249-255.

Oro A and Tadvald M (2018) A Igreja Universal do Reino de Deus no espaço público religioso global. Revista da Faculdade de Letras. Sociologia 36(1): 51-70.

Pew (2006) Many Americans Uneasy with Mix of Religion and Politics. Pew Research Center's Religion \& Public Life Project. Report. Washington, D.C.

Robertson R (2012) Globalisation or glocalisation? Journal of International Communication 18(2): 191-208.

Roof W (1993). Spiritual Marketplace Baby Boomers and the Remaking of American Religion. Princeton University Press.

Smith R (2013) More desired than our own salvation: the roots of Christian Zionism. Oxford: Oxford University Press.

Spector S (2009) Evangelicals and Israel: the story of American Christian Zionism. Oxford: Oxford University Press.

Schwarz R (1992) Misplaced Ideas: Essays on Brazilian Culture. London: Verso.

Topel F (2011) A inusitada incorporação do judaísmo em vertentes cristãs brasileiras algumas reflexões. Revista Brasileira de História das Religiões IV (10): 35-50.

Westbrook M (2014) The International Christian Embassy, Jerusalem and Renewalist Zionism: Emerging Jewish-Christian Ethnonationalism. PhD thesis. Drew University, U.S.

Williams J (2015). The Pentecostalization of Christian Zionism. Church History. 84. 159-194. 